\title{
Measurement of fuel consumption and harmful emissions of cars when using different types of fuel
}

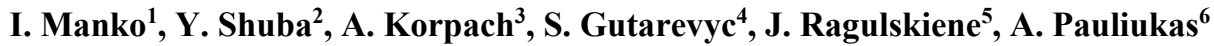 \\ ${ }^{1}$ Customer 1st Operations Department, Service Section, CFI "Toyota-Ukraine”, 24-V, Stepan Bandera \\ Ave., Kyiv, 04073, Ukraine \\ ${ }^{2,3}$ Department of Engines and Thermal Engineering, Faculty of Automotive and Mechanical Engineering, \\ National Transport University, Mykhaila Omelianovycha-Pavlenka Str. 1, 01010, Kyiv, Ukraine \\ ${ }^{4}$ Department of Motor Vehicle Maintenance and Service, Faculty of Automotive and Mechanical \\ Engineering, National Transport University, Mykhaila Omelianovycha-Pavlenka Str. 1, 01010, \\ Kyiv, Ukraine \\ ${ }^{5}$ Department of Mathematical Modelling, Kaunas University of Technology, \\ Studentu Str. 50-146, LT-51368, Kaunas, Lithuania \\ ${ }^{6}$ Institute of Power and Transport Machinery Engineering, Faculty of Agricultural Engineering, \\ Vytautas Magnus University, Studentų Str. 11, LT-53361, Akademija, Kaunas District, Lithuania \\ ${ }^{1}$ Corresponding author \\ E-mail: ${ }^{1}$ Ivan.Manko@toyota.ua, ${ }^{2}$ shuba@ntu.edu.ua, ${ }^{3}$ akorpach@ukr.net, ${ }^{4}$ sergutar@gmail.com, \\ jurate.ragulskiene@ktu.lt, ${ }^{6}$ arvydas.pauliukas@vdu.lt
}

Received 28 September 2020; received in revised form 12 December 2020; accepted 22 December 2020 DOI https://doi.org/10.21595/jme.2020.21847

Check for updates

Copyright (C) 2020 I. Manko, et al. This is an open access article distributed under the Creative Commons Attribution License, which permits unrestricted use, distribution, and reproduction in any medium, provided the original work is properly cited.

\begin{abstract}
The article presents the results of studies of energy, environmental and fuel efficiency indicators of a passenger car with a gasoline injection system. The engine is equipped with a device additionally supplying liquefied petroleum gas (LPG) and it has an ignition timing variator (ITV). As a result of research, an improvement in the fuel efficiency of a car in thermal equivalent was found when the engine was running on LPG and a slight increase in energy performance was observed. Emissions of pollutants with exhaust gases change in different ways: emissions of carbon monoxide practically do not change, emissions of hydrocarbons and nitrogen oxides are growing, carbon dioxide emissions from LPG operation are reduced, socio-economic damage when the engine is running on LPG is also reduced.
\end{abstract}

Keywords: measurement of fuel consumption, harmful emissions, liquefied petroleum gas, ignition timing variator.

\section{Introduction}

One of the directions of expanding the fuel base of road transport is the use of liquefied petroleum gas (LPG) along with gasoline and diesel fuel. One of the ways to expand the use of LPG is to retrofit a car engine with a gasoline injection system to the LPG power supply system. Such equipment is especially widely used in privately owned cars. This is due to the desire of car owners to reduce fuel costs, as the cost of LPG traditionally remains lower than the cost of gasoline, and the process of retrofitting does not require significant design changes. The expansion of the retrofitting process is facilitated by the growing number of service stations involved in the conversion of cars to gas fuel. It should also be noted that the network of gas stations is constantly growing.

Giving clear recommendations on the feasibility of retrofitting a petrol engine to enable LPG to be supplied is a very difficult task. The answer should take into account a large number of positive and negative points, each of which is not separate, but depends on many factors.

Research on the use of LPG as a motor fuel continues in different countries and now [1-5]. For example, in [1] the retrofitting of a serial car with a gasoline engine to the liquefied petroleum gas supply system is considered as a medium-term perspective in the transition to sustainable fuels and transport. The article [4] presents the results of bench studies of engine performance for work on liquefied petroleum gas. As a result of research, $\mathrm{CO}$ emissions were reduced by $15.97 \%$, HC 
emissions by $21.19 \%$, and $\mathrm{CO}_{2}$ emissions by $6.84 \%$. In [3], 26 liquefied gas taxis in Guangzhou, southern China, were tested using a chassis dynamometer. Concentrations of nitrogen oxides (NOx) and volatile organic compounds (VOCs) were measured during engine idling and modes corresponding to city traffic (at a speed of $10-60 \mathrm{~km} / \mathrm{h}$ ). As a result, it is established that the conversion of cars for the use of LPG will reduce greenhouse gas emissions only if the use of additional means for the purification of exhaust gases is applied. It is also advisable to establish additional control over cars running on LPG.

Comprehensive studies of a car with a gasoline injection system equipped with a modern LPG injection system have not been conducted. Therefore, it is advisable to determine the impact of this type of fuel on the performance of the car, compare them with the performance of gasoline and justify the feasibility of such equipment. The research is devoted to solve this problem and perform the investigation, the results of which are presented in the article.

\section{Research procedure and equipment}

The object of research was a serial car Daewoo Lanos 2007. It is equipped with a four-cylinder, four-stroke gasoline engine A15SMS with liquid cooling system and spark ignition. Such cars are widely used in operation. The main technical characteristics of the car, which are used in the study, are shown in Table 1.

Table 1. The main technical characteristics of the car Daewoo Lanos [6]

\begin{tabular}{|c|c|}
\hline Parameters & Value \\
\hline \multicolumn{2}{|c|}{ Equipped weight / full, kg } \\
\hline Type & Gasoline with distributed injection \\
\hline Displacement, $\mathrm{cm}^{3}$ & 1498 \\
\hline Cylinder diameter / piston stroke & $76,5 / 81,5$ \\
\hline Compression ratio & 9,5 \\
\hline Maximum power, hp (kW) & $86(63)$ \\
\hline Location, number of cylinders / valves per cylinder & In line, 4/2 \\
\hline Maximum torque, N m & 130 \\
\hline Transmission & Front-wheel drive \\
\hline Drive type & Mechanical, 5-step \\
\hline Gearbox &
\end{tabular}

When retrofitting a car with a gasoline engine, the LPG power supply system analyzes ways to improve engine performance using LPG properties that are better than those of gasoline. One of these properties is a higher octane number of LPG compared to gasoline. In order to use a high octane number of LPG, an increase in the degree of compression is used, which is impractical for two-fuel engines in operation, as this leads to detonation when running on gasoline. To increase the filling factor of the cylinders, the engine is equipped with a compressor for supercharging air, which in turn is quite expensive and requires design changes. In this case, the design of the engine imposes appropriate restrictions on the possibility of realizing the positive properties of the gas in the direction of increasing power, improving fuel economy and reducing toxicity. At the same time, the current demand for such power plants requires the identification of the most suitable ways to improve their fuel efficiency, energy, environmental performance and general performance. Among the ways to increase the use of positive qualities of LPG, which would not affect the performance of the basic gasoline supply system and do not require complex design changes, is the installation of modern gas cylinder equipment, which cooperates with the standard engine control system and allows precise control of gas supply to cylinders influencing ignition advance angle when the car is running on LPG. Therefore, these issues can be fully or partially solved either by making design changes to the engine system, which is undesirable in operation, or by optimizing the basic engine controls, namely the ignition advance angle and the composition 
of the working mixture, which is simpler and more accessible. Important factors to consider when choosing the optimal values of the ignition advance angle are that the combustion rate of the gas-air mixture is lower, and the ignition delay period is longer than of the gas-air mixture. It is especially important that the optimal values of the ignition advance angle on gas fuel in the mode of maximum efficiency $(\lambda=1.3)$ are greater than on gasoline in the same mode $(\lambda=1.1)$. It is interesting that with increasing degree of compression of the base engine, this difference decreases. It follows that when changing the type of fuel from gasoline to gas, the ignition advance angle should be increased to the optimal value, which should be determined with sufficient accuracy and scientifically substantiated [7]. It should be noted that under operating conditions, the most accessible way to change the ignition advance angle is to install an ignition advance variator (IED), which allows to perform the change of its setting value [8].

To reduce the amount of other harmful substances, it is necessary that the gas engine has optimally adjusted fuel equipment and ignition system, which allows one to organize the workflow with maximum efficiency [9-10]. It should be borne in mind that the feasibility of using gas-balloon vehicles for the rehabilitation of the air pool must be assessed in relation to the existing background pollution, taking into account that their toxicity is mainly due to emissions of nitrogen oxides [6], crucial in the formation of which is the value directly affected by the ignition advance angle $[11,12]$. Based on the general idea of NOx formation in the engine displacement, according to which the composition of the working mixture and the maximum temperatures of the combustion process are significant in this case, it is almost impossible to achieve simultaneous reduction of NOx emissions and increase the efficiency of the working process. However, as is known, along with slight differences in the formation of $\mathrm{NO}_{\mathrm{x}}$ in gasoline and gas engines in operating modes close to full load mode, a significant part of $\mathrm{NO}_{\mathrm{x}}$ emissions is due to partial loads, when the gas engine has high efficiency combined with lower $\mathrm{NO}_{\mathrm{x}}$ content in exhaust gases, compared to a gasoline engine. However, despite the fact that both of these indicators of the working process are dependent on the general physicochemical conditions of combustion of the working mixture, they can be adjusted in a fairly wide range with different angles of ignition advance and the composition of the mixture. The ignition advance angle in different operating modes directly affects the emission of CL. However, it is necessary to take into account the fact that toxicity control may impair some driving qualities, increase fuel consumption and reduce engine power [13]. It should be noted that under operating conditions, the control parameters, in particular the ignition advance angle, should change automatically depending on the type of fuel. Since the beginning of the use of liquefied petroleum gas as a motor fuel in road transport, appropriate power supply systems have been developed that would allow to use the positive qualities of gaseous fuel with the highest efficiency in internal combustion engines with different types of mixing, ignition of the working mixture and workflow [14]. Based on the analysis of known LPG supply systems, taking into account the complexity of installation and the possibility of using high-quality LPG properties, a fourth-generation gas supply system was selected for installation, which is a distributed injection system and above, and on-board diagnostic systems OBD II and EOBD (Fig. 1).

These systems use computing power and fuel supply maps laid down in the regular EBC, and only the necessary corrections are made to adapt the gas system to the gasoline fuel supply map. As in the previous generation, these systems use injectors that are mounted on the intake manifold directly next to the intake valve of each cylinder, but no longer mechanical, but with solenoid valves.

The fifth-generation gas cylinder equipment (HBO) differs from the fourth in the fact that the gas is supplied to the intake valves in a liquid state. To do this, a gas pump is installed in the cylinder, which ensures the circulation of the liquid phase of the gas from the cylinder to the gas injector ramp and through the valve of excess pressure again into the cylinder.

The sixth generation of HBO is a system of gas injection in the liquid state similar to the previous one, but directly into the engine cylinders. 


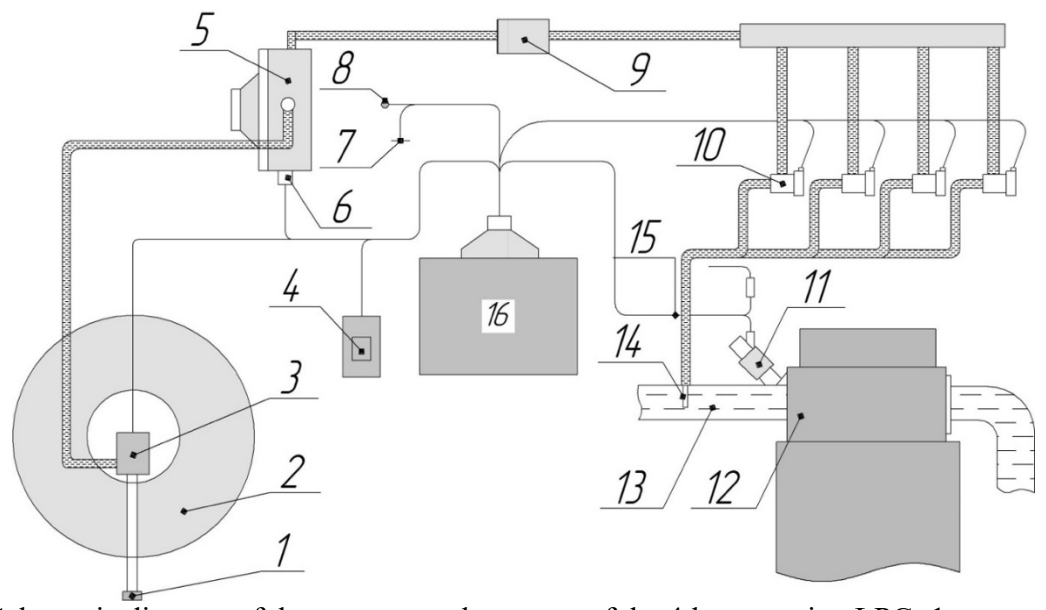

Fig. 1. Schematic diagram of the power supply system of the 4th generation LPG: 1 - remote filling device; 2 - balloon; 3 - multivalve; 4 - fuel type switch; 5 - the reducer evaporator; 6 - temperature sensor; 7 - grounding on the car body; 8 - "+" battery; 9 - fine filter; 10 - gas nozzles; 11 - gasoline injector; 12 - engine; 13 - intake manifold; 14 - gas fitting; 15 - cable emulator gasoline injectors; 16 - gas EBK

An important advantage of systems 3, 4, 5, 6 generations is the function of automatic transition from gas to gasoline, at the end of the gas or when it is impossible to use gas in some loading modes.

The advantages of the fifth and sixth generations include the ability to start the engine on gas at any negative temperatures, as there is no need to evaporate the gas before it is fed into the engine. The disadvantages of the systems include their high sensitivity to gas quality, low maintainability and high complexity.

After analyzing the LPG power supply systems, we can conclude that the most promising for installation on the car in operation are the fourth generation power supply systems, as they meet high environmental requirements, work properly with regular EBC and are not very demanding on LPG quality [15].

When installing the LPG power supply system on an engine with a gasoline injection system, the normative provisions were observed, which are mandatory when installing gas cylinder equipment [16-18].

The study of the impact of the type of fuel (gasoline or LPG) on the performance of the Daewoo Lanos was conducted on the stand and in road conditions Fig. 2. The scheme of the experimental installation for bench tests is shown in Fig. 3.

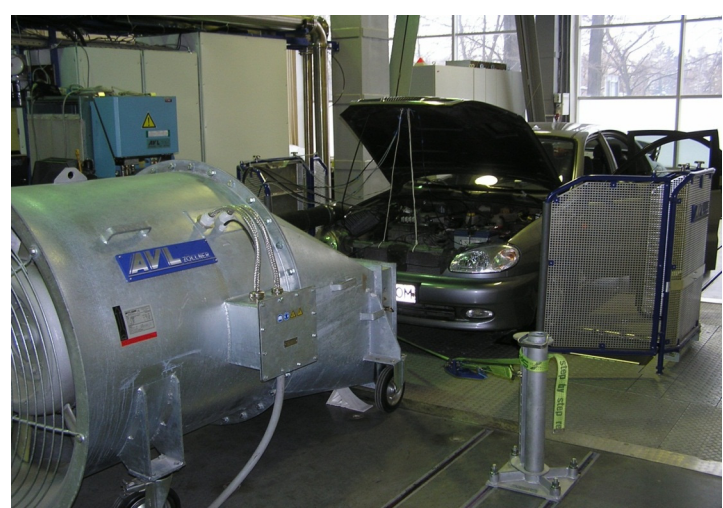

Fig. 2. Object of experimental research during bench tests 


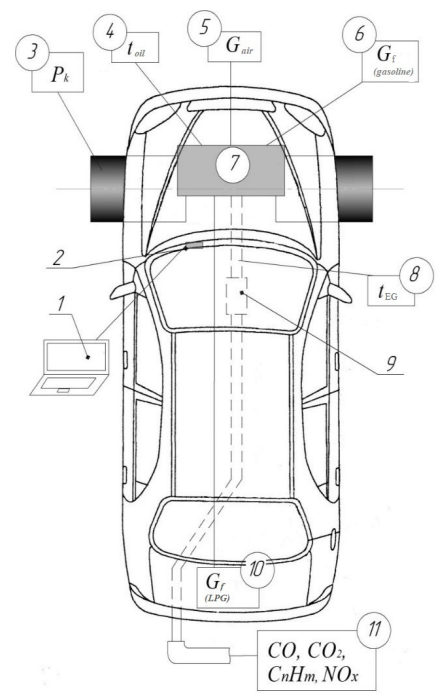

Fig. 3. Scheme of the experimental installation for bench research: 1 - laptop; 2 - diagnostic connector of the car; 3 -drums of the roller modeling stand; 4 - device for determining the engine oil temperature;

5 - device for determining air flow; 6 - device for determining the consumption of gasoline;

7 - car engine; 8 - device for determining the temperature of the exhaust gases; 9 - catalytic converter VG; 10 - device for determining the consumption of LPG; 11 - universal CVS constant sampling system

Bench experimental tests were performed on a simulation roller stand AVL-Zollner type RPL1220 / 12C23M17 / APM150 (factory No. R1305), which provided the required traction on the wheels and the speed of the car during the test, that are provided by the driving cycle program. The main technical characteristics of the stand are given in the Table 2.

Table 2. Technical characteristics of the modeling roller stand AVL-Zollner

\begin{tabular}{|c|c|}
\hline Paximum speed, $\mathrm{km} / \mathrm{h}$ & Value \\
\hline Maximum traction force, $\mathrm{N}$ & 200 \\
\hline Weight of rotating parts, $\mathrm{kg}$ & 10096 \\
\hline Minimum adjusted weight of rotating parts, $\mathrm{kg}$ & 1184 \\
\hline Maximum adjusted weight of rotating parts, $\mathrm{kg}$ & 544 \\
\hline The diameter of the drum, mm & 1219,2 \\
\hline The error in power measurement, \% & $<0,10$ \\
\hline The error in measuring speed, \% & $<0,01$ \\
\hline The error in the measurement of acceleration, \% & $<1$ \\
\hline The error in the measurement of mechanical losses, $\mathrm{H}$ & $<5$ \\
\hline The error in determining the time, ms & 10 \\
\hline The error in determining the constant speed, \% & $<0,05$ \\
\hline The error in determining the steady traction, \% & $<0,2$ \\
\hline The error in determining simulated load, \% & $<2$ \\
\hline The error in determining the moment of inertia simulation, \% & $<1$ \\
\hline
\end{tabular}

A-95 gasoline and propane-butane automobiles were used in the research. Fuel characteristics are given in the Table 3 .

Gas consumption during bench research was determined by a mass flowmeter of Corlex fuel type FlexCOR, which was connected to the gap of the high pressure fuel line between the gas cylinder and the reducer, and gasoline consumption - gravimetric fuel flow meter AVL model 733S.18, from which the car engine was powered.

To measure the air flow rate a mass air flow meter GF-90-A1A00ADAA00060DA5A4, head No. 237506, with a measuring range of $8 \ldots 1200 \mathrm{~m}^{3} / \mathrm{h}$, was used. 
To determine the amount of harmful substances in the VG, a universal sampling system of constant volume (CVS system model "EMMS-CVS-010") was used, followed by analysis of the contents of the bags to be sampled, gas analyzer MEXA-7400DEGR manufactured by Horiba Ltd. (Japan), which includes gas analyzers AIA-721 CO (head No. 6423004), AIA-722 CO / $\mathrm{CO}_{2}$ (head No. 06420007), MPA-720 $\mathrm{O}_{2}$ (head No. 29416005), and unit OVN-728A (head No. 430148001), which houses gas analyzers FIA-725 AHTHC, CLA-755 A, H.NO/NOx and FIA-712HA. H.THC / CH4, were used.

Table 3. Characteristics of the fuels used

\begin{tabular}{|c|c|c|c|c|}
\hline \multicolumn{2}{|c|}{ Fuel characteristics } & A-95 gasoline & \multicolumn{2}{|c|}{ LPG } \\
\hline \multirow{2}{*}{ The proportion of the mixture } & & - & Propane & 0,5 \\
\cline { 4 - 5 } & & & Butane & 0,5 \\
\hline \multirow{2}{*}{ Density (liquid phase), $\mathrm{kg} / 1$} & \multirow{2}{*}{$\rho$} & - & Propane & 0,509 \\
\cline { 4 - 5 } & & & Butane & 0,584 \\
\hline Fuel density, $\mathrm{kg} / \mathrm{l}$ & & $0,71-0,76$ & Mixture & 0,546 \\
\hline \multirow{2}{*}{ Lower heat of combustion, mass, MJ / kg } & \multirow{2}{*}{$H_{u}$} & \multirow{2}{*}{44,000} & Propane & 45,938 \\
\cline { 4 - 5 } & & & Butane & 45,406 \\
\cline { 4 - 5 } & & & Mixture & 45,672 \\
\hline Theoretically, the required amount of air & $l_{0}$ & $14,5-15,0$ & Mixture & 15,57 \\
\hline
\end{tabular}

The principle of operation of devices for determination of concentrations of harmful substances in VG is the following: carbon monoxide $\mathrm{CO}$ and carbon dioxide $\mathrm{CO}_{2}-$ gas analyzer of non-dispersive type with absorption in infrared rays (NDIR); $\mathrm{C}_{\mathrm{m}} \mathrm{H}_{\mathrm{n}}$ hydrocarbons - propanecalibrated flame-ionization gas analyzer; NOx nitrogen oxides - chemiluminescent type gas analyzer (CLA) with $\mathrm{NO}_{\mathrm{x}} / \mathrm{NO}$ converter.

The main metrological characteristics of the gas analytical complex are given in the Table 4 .

Table 4. Basic metrological characteristics

\begin{tabular}{|c|c|c|c|c|}
\hline \multirow{2}{*}{$\begin{array}{l}\text { The indicator to be determined } \\
\text { (designation of the gas analyzer) }\end{array}$} & \multirow{2}{*}{$\begin{array}{l}\text { Measuring range of } \\
\text { volume content }\end{array}$} & \multirow{2}{*}{ Measurement range } & \multicolumn{2}{|c|}{ Permissible error } \\
\hline & & & Absolute & Relative \\
\hline $\begin{array}{c}\mathrm{CO} \\
(\mathrm{AIA}-721 \mathrm{CO})\end{array}$ & $0-0,5 \%$ & $\begin{array}{l}0-0,2 \% \\
\text { over } 0,2 \%\end{array}$ & $\begin{array}{c} \pm 0,01 \% \\
-\end{array}$ & $\begin{array}{c}- \\
\pm 5 \%\end{array}$ \\
\hline $\begin{array}{c}\mathrm{CO} \\
\left(\mathrm{AIA}-722 \mathrm{O} / \mathrm{CO}_{2}\right)\end{array}$ & $0-12 \%$ & $\begin{array}{l}0-0,6 \% \\
\text { over } 0,6 \%\end{array}$ & $\begin{array}{c} \pm 0,03 \% \\
-\end{array}$ & $\begin{array}{c}- \\
\pm 5 \%\end{array}$ \\
\hline $\begin{array}{c}\mathrm{CO}_{2} \\
\left(\mathrm{AIA}-722 \mathrm{O} / \mathrm{CO}_{2}\right)\end{array}$ & $0-20 \%$ & $\begin{array}{l}0-10 \% \\
\text { over } 10 \%\end{array}$ & $\begin{array}{c} \pm 0,5 \% \\
-\end{array}$ & $\begin{array}{c}- \\
\pm 5 \%\end{array}$ \\
\hline $\begin{array}{c}\mathrm{C}_{\mathrm{m}} \mathrm{H}_{\mathrm{n}} \\
\text { (FIA-725 A.H.THC) }\end{array}$ & $0-5 \%$ & $\begin{array}{c}0-0,02 \% \\
\text { over } 0,02 \%\end{array}$ & $\begin{array}{c} \pm 0,001 \% \\
-\end{array}$ & $\begin{array}{c}- \\
\pm 5 \%\end{array}$ \\
\hline $\begin{array}{c}\mathrm{CH}_{4} \\
\text { (FIA-712 HA.H.THC/CH} \text { ) }\end{array}$ & $0-0,25 \%$ & $\begin{array}{c}0-0,02 \% \\
\text { over } 0,02 \%\end{array}$ & $\begin{array}{c} \pm 0,001 \% \\
-\end{array}$ & $\begin{aligned} & - \\
\pm & 5 \%\end{aligned}$ \\
\hline $\begin{array}{c}\mathrm{NO}_{\mathrm{x}} \\
\left(\mathrm{CLA}-755 \mathrm{~A}, \mathrm{H} . \mathrm{NO} / \mathrm{NO}_{\mathrm{x}}\right)\end{array}$ & $0-0,5 \%$ & $\begin{array}{l}0-0,04 \% \\
\text { over } 0,04 \%\end{array}$ & $\begin{array}{c} \pm 0,002 \% \\
-\end{array}$ & $\begin{array}{c}- \\
\pm 5 \%\end{array}$ \\
\hline $\begin{array}{c}\mathrm{O}_{2} \\
\text { (MPA-720 O2) }\end{array}$ & $0-0,5 \%$ & $\begin{array}{c}0-0,04 \% \\
\text { over } 0,04 \%\end{array}$ & $\begin{array}{c} \pm 0,002 \% \\
-\end{array}$ & $\begin{array}{c}- \\
\pm 5 \%\end{array}$ \\
\hline
\end{tabular}

Parameters such as throttle position, intake manifold vacuum, coolant temperature, ignition advance angle during bench tests were determined using a laptop with the appropriate software installed, which was connected to the vehicle's diagnostic connector.

During road tests, the purpose of which was to determine the fuel characteristics of the steady movement of the car, gasoline consumption was determined by a fuel flow meter of the volume type. Gas fuel consumption was determined by the mass method, using scales, by weighing the gas cylinder from which the car engine was powered before and after arrival.

When performing studies of traction and speed properties, which estimated the acceleration time of the car from 20 to $90 \mathrm{~km} / \mathrm{h}$ with a fixed value of the throttle opening (70\%) when working 
on both fuels, the data were recorded using a laptop with appropriate software connected to diagnostic connector of the car through the K-line adapter.

\section{The results of bench research of the car for work on gasoline and LPG}

Bench studies aimed at determining and comparing the fuel-economic and environmental performance of the car were conducted in two stages. The first stage was to determine the load characteristics of the engine in a wide range of speed and load modes when powered by gasoline and LPG. In Fig. 4, as an example, the load characteristic of the A15SMS engine at a crankshaft speed $n=2400 \mathrm{~min}^{-1}$ when powered by gasoline and LPG are shown. The characteristics show that the transfer of the car to the LPG has led to improved fuel economy. The reduction in specific fuel consumption on average on the load characteristic is $8.6 \%$. The energy performance of the engine increased slightly, at full load the engine torque during operation on LPG increased by about $3 \%$.

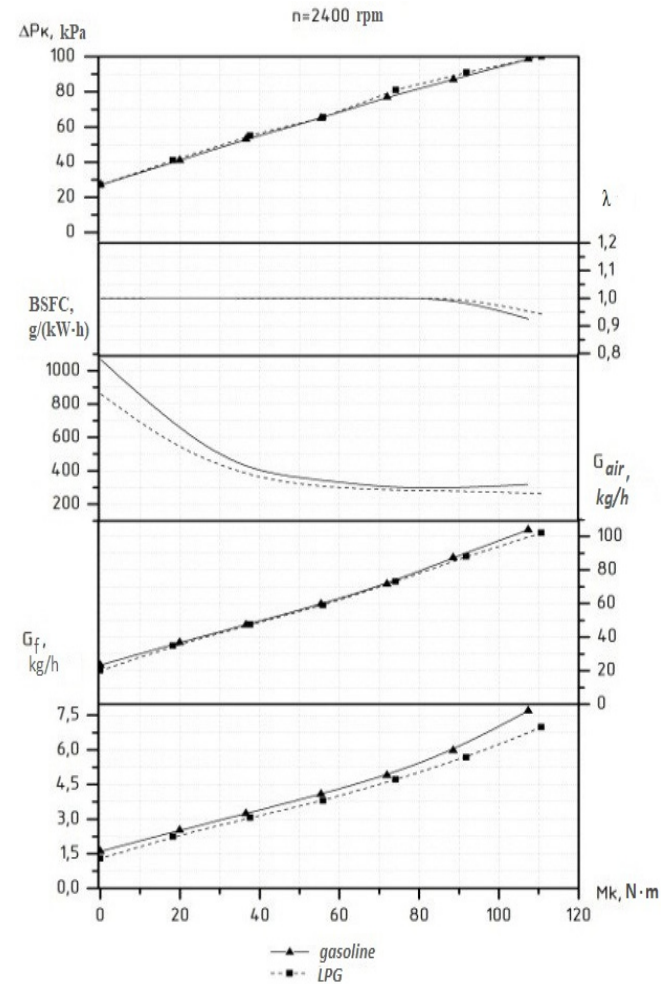

a) Fuel and economic indicators

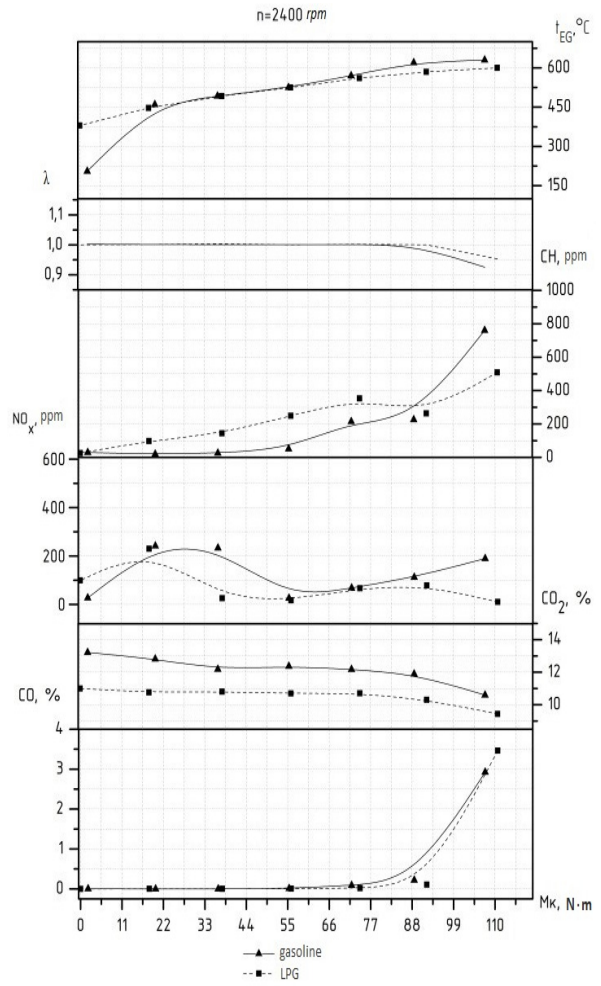

b) Environmental indicators

Fig. 4. Load characteristics of the Daewoo Lanos engine powered by gasoline and LPG

The content of carbon monoxide $\mathrm{CO}$ and nitrogen oxides $\mathrm{NOx}$ in the engine $\mathrm{VG}$ when running on LPG is almost the same as on gasoline, although in the load modes at a speed of $1600 \mathrm{~min}^{-1}$ there is an increase in nitrogen oxides $\mathrm{NO}_{\mathrm{x}}$ when working on LPG. In turn, the amount of $\mathrm{C}_{\mathrm{m}} \mathrm{H}_{\mathrm{n}}$ hydrocarbons, in the modes of low and medium loads, has doubled, and the content of carbon dioxide $\mathrm{CO}_{2}$ has decreased by an average of about $14 \%$.

The temperature of the exhaust gases is almost the same when working on both types of fuel in the entire range. The coefficient of excess air $\alpha$ is maintained at about one in the modes of low and medium loads, both when working on gasoline and LPG, due to the presence of an oxygen sensor in the exhaust system.

One of the most used modes of operation of automobile engines in the conditions of operation, 
in particular in cities and settlements, are the idling modes. Therefore, the comparative characteristics of the engine were determined for work on both types of fuel in this mode (Fig. 5).

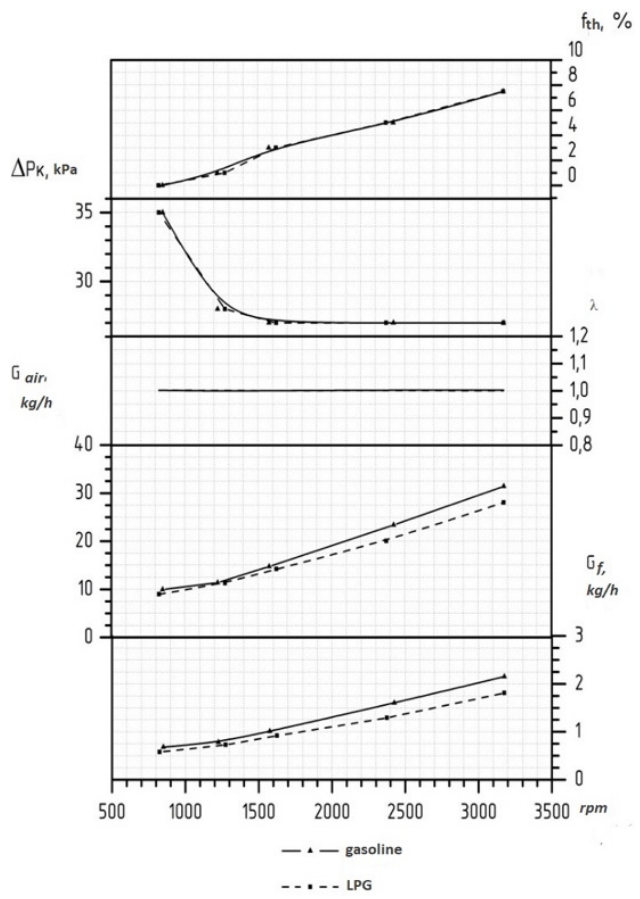

a) Fuel and economic indicators

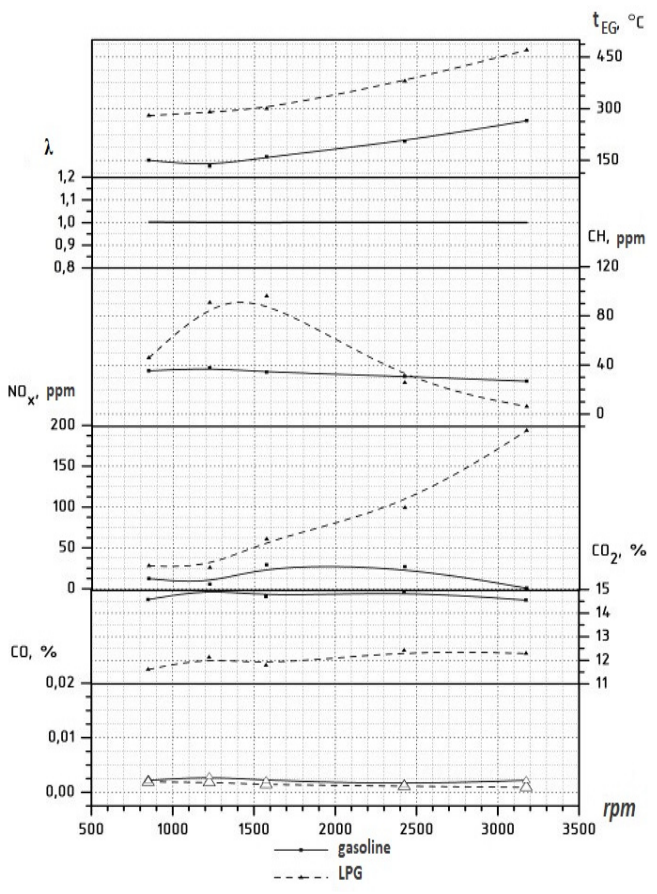

b) Environmental indicators

Fig. 5. Speed characteristics of active idling of the engine of the Daewoo Lanos car when working on gasoline and LPG

The increase in the speed of the engine crankshaft is provided by the opening of the throttle valve $\varphi_{D R}=0 \ldots 7.5 \%$. Hourly consumption of gas fuel, expressed in mass units $(\mathrm{kg} / \mathrm{h})$, on average in terms of speed is less than the consumption of gasoline by about $16 \%$. The fuel consumption $G_{p}$, when working on gasoline, increases from 0.69 to $2.33 \mathrm{~kg} / \mathrm{h}$, and air consumption $G_{\text {pov }}$ from 10.11 to $34 \mathrm{~kg} / \mathrm{h}$. When working on LPG fuel consumption increases from 0.58 to $1.81 \mathrm{~kg} / \mathrm{h}$, and air $G_{\text {pov }}$ - from 8.96 to $28.06 \mathrm{~kg} / \mathrm{h}$.

Also, the characteristics of active idling show that as a result of converting the car to LPG, the amount of $\mathrm{C}_{\mathrm{m}} \mathrm{H}_{\mathrm{n}}$ hydrocarbons increased by an average of $60.7 \%$, and nitrogen oxides NOx by about five times, due to an increase in $\mathrm{HV}$ temperature. The content of carbon oxides $\mathrm{CO}$ remained almost unchanged, and the content of carbon dioxide $\mathrm{CO}_{2}$ decreased by approximately $18 \%$.

The temperature of the exhaust gases $t_{v g}$ when working on LPG is greater in the whole speed range by about $150^{\circ} \mathrm{C}$, and the coefficient of excess air $\alpha$ is the same and equal to one.

The second stage of the bench tests was an experimental test of a car in motion according to the European Urban Driving Cycle, according to UNECE Regulations No. 83, on a modeling AVL roller stand, which was adjusted according to the car's weight.

As a result of the conducted researches experimental values of fuel consumption and ecological indicators at movement of the car on gasoline and LPG on the European city driving cycle which are given in Table 5 were received.

These data show that the consumption of LPG per cycle in mass units is less than the consumption of gasoline by $13 \%$, and in volume units is higher by $16.8 \%$. The fuel consumption per cycle, expressed in thermal equivalent, when working on LPG is less than when working on gasoline by $10 \%$. 
It is also seen that the values of mass emissions of carbon monoxide per cycle are almost the same for both fuels. The amount of hydrocarbons when working on LPG is about 6 times greater, and the amount of nitrogen oxides -1.6 times. Mass emissions of carbon dioxide from the power supply of the LPG car decreased by $18.3 \%$.

Despite the fact that mass $\mathrm{CO}_{2}$ emissions are not regulated in accordance with the requirements of Euro II, it can be noted that the transition to LPG will significantly reduce them. This will help to reduce the harmful effects of road transport on the environment, in particular in terms of greenhouse effects.

At the same time, it should be noted that although environmental indicators are deteriorating somewhat, in particular, increasing emissions of $\mathrm{C}_{\mathrm{m}} \mathrm{H}_{n}$ hydrocarbons and NOx nitrogen oxides, Euro II standards are met on both gasoline and LPG.

Table 5. The results of experimental studies

\begin{tabular}{|c|c|c|c|c|c|c|c|c|}
\hline Fuel & $\begin{array}{c}\text { Consumption } \\
\text { per cycle, } \mathrm{g}\end{array}$ & $\begin{array}{c}\text { The amount } \\
\text { of heat per } \\
\text { cycle, } \mathrm{kJ}\end{array}$ & $\begin{array}{c}\text { Consumption, } \\
1 / 100 \mathrm{~km}\end{array}$ & $\begin{array}{c}\mathrm{CO}, \\
\mathrm{g} / \mathrm{km}\end{array}$ & $\begin{array}{c}\mathrm{CH}, \\
\mathrm{g} / \mathrm{km}\end{array}$ & $\begin{array}{c}\mathrm{NO}_{\mathrm{x}}, \\
\mathrm{g} / \mathrm{km}\end{array}$ & $\begin{array}{c}\mathrm{CO}_{2}, \\
\mathrm{~g} / \mathrm{km}\end{array}$ & $\begin{array}{c}\mathrm{CH}+ \\
\mathrm{NO}_{\mathrm{x}}, \\
\mathrm{g} / \mathrm{km}\end{array}$ \\
\hline Gasoline & 74,54 & 3280 & 9,94 & 0,019 & 0,035 & 0,142 & 217,81 & 0,177 \\
\hline LPG & 64,24 & 2955 & 11,61 & 0,018 & 0,183 & 0,233 & 177,89 & 0,416 \\
\hline Euro II & \multicolumn{3}{|c}{-} & 2,2 & \multicolumn{3}{c|}{-} & 0,5 \\
\hline
\end{tabular}

\section{The results of road tests of the car}

The assessment of the fuel efficiency of the car when powered by gasoline and LPG was carried out on the fuel characteristics of steady traffic. These indicators do not have standardized values, they are used to compare the fuel efficiency of similar cars of different brands or one car when powered by different types of fuels.

Determination of the fuel characteristics of steady motion was performed in accordance with GOST 20306 - 90 when powered by gasoline and LPG.

The races were performed on a measuring section $2 \mathrm{~km}$ long with constant speeds of the car in the speed range from 20 to $100 \mathrm{~km} / \mathrm{h}$ with a step of $20 \mathrm{~km} / \mathrm{h}$.

The tests were performed in compliance with the following requirements:

- test races on the road were conducted in opposite directions at least twice at each speed;

- the time of passage of the site and the amount of fuel used was recorded in each direction of movement;

- the test was repeated if the difference between the results obtained in any two races exceeds $5 \%$. The results of measurements were taken as the arithmetic mean of the races;

- the set speed of the car in the race was set before entering the measuring area.

The test results are given in the Table 6 .

Table 6. Fuel characteristics of steady motion

\begin{tabular}{|c|c|c|c|c|c|c|}
\hline \multirow{2}{*}{ Speed, km/h } & \multicolumn{2}{|c|}{ Gasoline } & \multicolumn{2}{c|}{ LPG with ITV } & \multicolumn{2}{c|}{ LPG without ITV } \\
\cline { 2 - 7 } & $\mathrm{g}$ & $1 / 100 \mathrm{~km}$ & $\mathrm{~g}$ & $1 / 100 \mathrm{~km}$ & $\mathrm{~g}$ & $1 / 100 \mathrm{~km}$ \\
\hline 20 & 228,56 & 7,72 & 180 & 8,79 & 200 & 9,225092 \\
\hline 40 & 167,49 & 5,66 & 120 & 5,86 & 142,5 & 6,595941 \\
\hline 60 & 160,21 & 5,41 & 135 & 6,59 & 132,5 & 6,134686 \\
\hline 80 & 162,45 & 5,48 & 152,5 & 7,47 & 145 & 6,688192 \\
\hline 100 & 196,06 & 6,62 & 177,5 & 8,64 & 162,5 & 7,51845 \\
\hline
\end{tabular}

The fuel characteristics of the steady movement of the car when powered by gasoline and LPG are shown in Fig. 6.

Analyzing this graph, it should be noted that in the speed range from 20 to $60 \mathrm{~km} / \mathrm{h}$ consumption of LPG in the case of ITV, expressed in volume units, is greater than the consumption of gasoline by $6.8 \%$, and when supplied with gas without ITV this difference is $16.8 \%$. When 
the car is moving in the speed range from 60 to $100 \mathrm{~km} / \mathrm{h}$, the consumption of LPG when using a variator is $26 \%$ higher than the consumption of gasoline, and without a variator $-17 \%$.
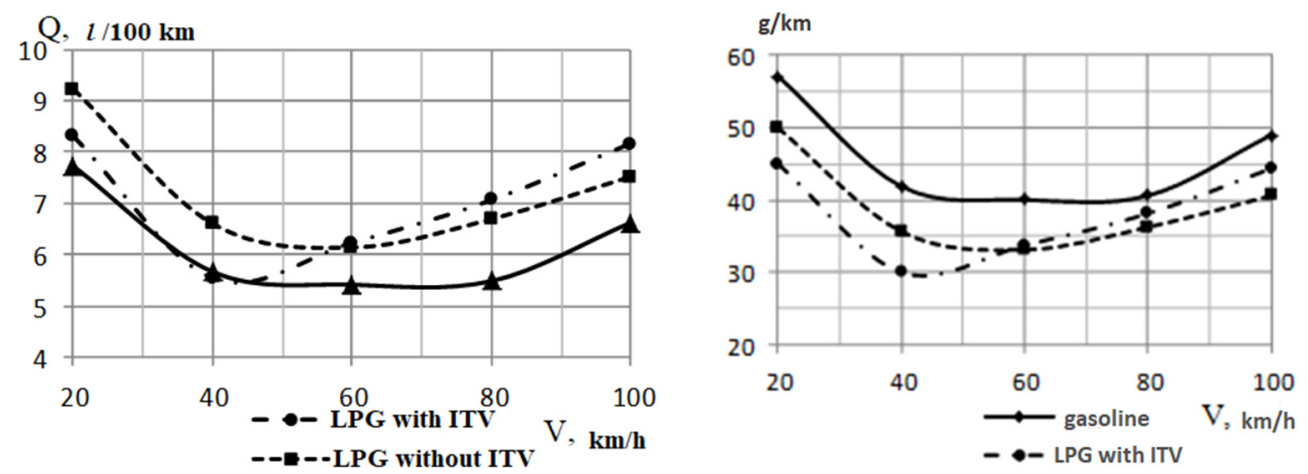

Fig. 6. Fuel characteristics of steady traffic

The most objective assessment of the fuel characteristics of the steady movement of the car when powered by gasoline and LPG can be based on the values of the heat consumed by the combustion of fuel per kilometer. Thus, the characteristic is shown in Fig. 7.

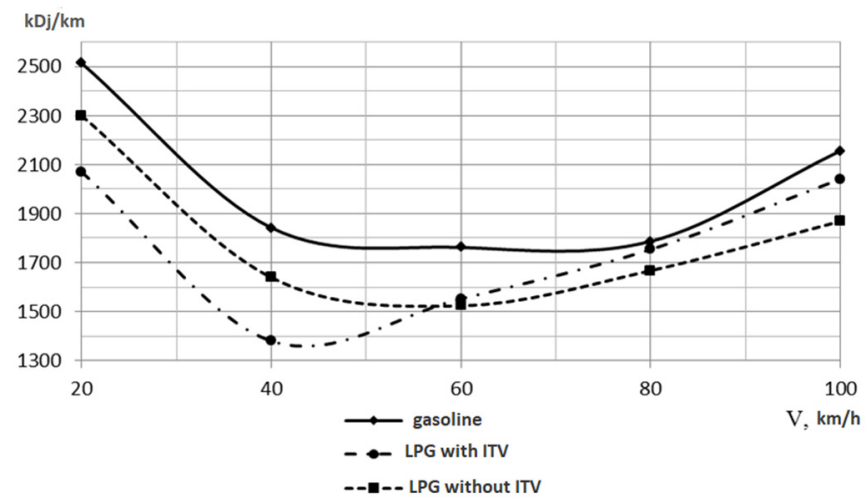

Fig. 7. Fuel characteristics of steady motion in energy units

From this characteristic it is seen that in the range of speeds from 20 to $60 \mathrm{~km} / \mathrm{h}$ the amount of heat of fuel combustion per one kilometer, in the case of powering the engine of a LPG car using ITV, is less than when powered by gasoline on average by $18 \%$, and when supplied with gas without the use of ITV - by $11 \%$. In the speed range from 60 to $100 \mathrm{~km} / \mathrm{h}$, the amount of heat of combustion of fuel per kilometer when powered by LPG using a variator is less than when working on gasoline by $3.6 \%$, and in the case of LPG without a variator, this difference was $10 \%$.

A number of indicators are used to assess the traction and speed properties of the car. One of the most used and sufficient is the time of acceleration of the car to a certain speed, usually $100 \mathrm{~km} / \mathrm{h}$, at maximum fuel supply. Under operating conditions, accelerations with a fully open throttle are rarely used. More often for accelerations of cars positions of a throttle valve to $50-70 \%$ are used. Therefore, the car was subjected to similar road tests, which were the acceleration of the car from 20 to $90 \mathrm{~km} / \mathrm{h}$ with a fixed value of the throttle opening $(70 \%)$ when working on both types of fuel. During the tests, the data was recorded using a laptop with the appropriate software installed connected to the diagnostic connector of the car via a K-line adapter. An example of recording the acceleration of the car is shown in Fig. 8.

The results of such accelerations are given in the Table 7 . 


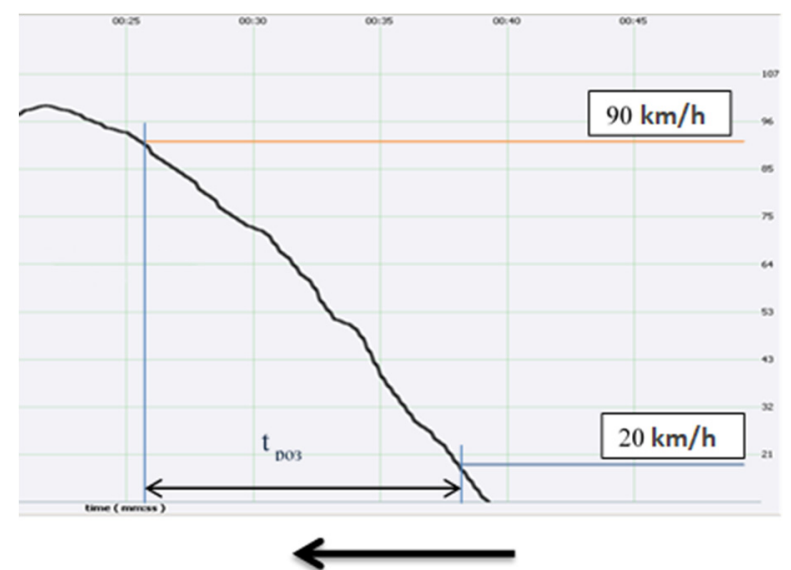

Fig. 8. Example of recording the acceleration of the car from 20 to $90 \mathrm{~km} / \mathrm{h}$ with a fixed opening of the throttle valve $\varphi=70 \%$

Table 7. The results of road tests of the car Daewoo Lanos

\begin{tabular}{|c|c|c|c|c|c|c|c|c|c|c|}
\hline \multirow{5}{*}{ No } & \multicolumn{10}{|c|}{ Fuel } \\
\hline & \multicolumn{5}{|c|}{ Gasoline } & \multicolumn{5}{|c|}{ LPG } \\
\hline & \multicolumn{10}{|c|}{ Acceleration time to speed $V_{a}, \mathrm{~s}$} \\
\hline & \multicolumn{5}{|c|}{ Speed $V_{a}, \mathrm{~km} / \mathrm{h}$} & \multicolumn{5}{|c|}{ Speed $V_{a}, \mathrm{~km} / \mathrm{h}$} \\
\hline & 20 & 40 & 60 & 80 & 90 & 20 & 40 & 60 & 80 & 90 \\
\hline 1 & 0 & 2,65 & 5,75 & 10,25 & 12,1 & 0 & 2,4 & 5,4 & 9,25 & 11,45 \\
\hline 2 & 0 & 2,25 & 5,85 & 10,05 & 12,45 & 0 & 2,05 & 4,95 & 9,05 & 10,75 \\
\hline 3 & 0 & 3,25 & 6,25 & 10,55 & 12,6 & 0 & 2,5 & 5,5 & 9,4 & 11,5 \\
\hline 4 & 0 & 3 & 5,75 & 9,9 & 12,25 & 0 & 2,05 & 4,95 & 8,85 & 10,8 \\
\hline 5 & 0 & 2,95 & 6,05 & 10,01 & 12,8 & 0 & 2,1 & 4,85 & 8,5 & 10,8 \\
\hline 6 & 0 & 2,3 & 5,3 & 9,7 & 12,1 & 0 & 2,3 & 5,1 & 9,1 & 11,1 \\
\hline$X$ & 0 & 2,733 & 5,825 & 10,077 & 12,383 & 0 & 2,233 & 5,125 & 9,025 & 11,067 \\
\hline$\sigma_{x}$ & & & & & $\pm 0,142$ & & & & & $\pm 0,139$ \\
\hline$\rho_{x}$ & & & & & $\pm 0,0958$ & & & & & $\pm 0,0938$ \\
\hline$\delta, \%$ & & & & & $\pm 0,77$ & & & & & $\pm 0,85$ \\
\hline
\end{tabular}

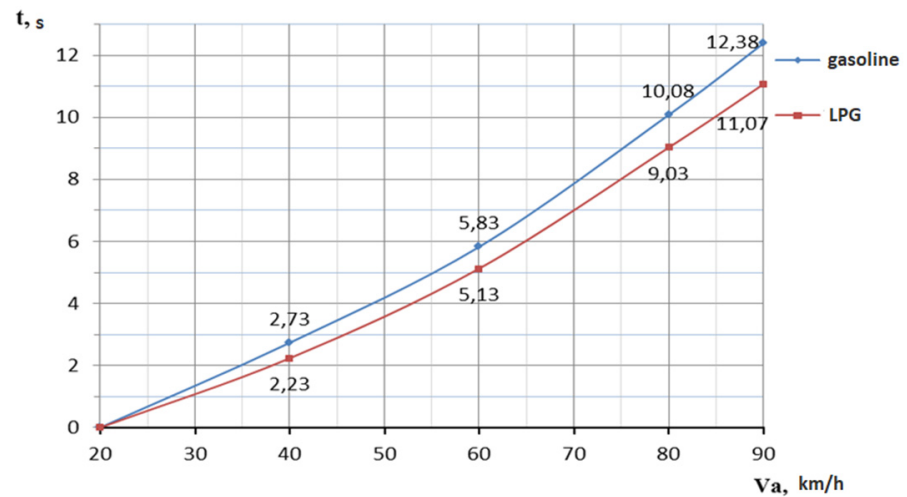

Fig. 9. Dynamics of acceleration of the car

The data in the table shows that the tests were performed correctly, because the standard deviations are insignificant. Based on the obtained data, a graph was constructed (Fig. 9), which clearly shows the acceleration time of the car from 20 to $90 \mathrm{~km} / \mathrm{h}$ when working on both types of fuel.

Analyzing this graph, we can say that when the car is running on LPG, the acceleration time 
decreased by about $1 \mathrm{~s}$. This indicates that the dynamics of the car when transferred to the LPG has not deteriorated, and even improved slightly.

\section{Errors of devices used during research}

In the Table 8 data on measuring equipment and instruments used during the tests is shown, from which it can be concluded that the instruments meet the requirements [17] for measuring equipment.

Table 8. Test equipment, measuring equipment and indicators of their accuracy

\begin{tabular}{|c|c|c|c|}
\hline $\begin{array}{c}\text { Name of measuring equipment, type, } \\
\text { brand, serial number }\end{array}$ & $\begin{array}{l}\text { The indicator is } \\
\text { set or determined }\end{array}$ & $\begin{array}{c}\text { Range or technical } \\
\text { characteristics }\end{array}$ & $\begin{array}{c}\text { Border acceptable } \\
\text { basic errors }\end{array}$ \\
\hline \multirow{3}{*}{$\begin{array}{l}\text { Modeling roller stand AVL type } \\
\text { RPL } 1220 \text { / } 12 \text { C } 23 \text { M } 17 / \\
\text { APM 150, Factory No. R-1305, } \\
\text { Inv. No. } 5184\end{array}$} & $\begin{array}{l}\text { Effort on the } \\
\text { surface of the } \\
\text { drum }\end{array}$ & $\begin{array}{c}(-10,0 \ldots+10,0) \\
\mathrm{kN}\end{array}$ & $\begin{array}{c}\text { Consolidated error } \\
\pm 0,1 \% \\
\text { from full scale }\end{array}$ \\
\hline & \multirow{2}{*}{ Car speed } & $(0 \ldots 2) \mathrm{km} / \mathrm{h}$ & $\begin{array}{c}\text { Consolidated error } \\
\pm 0,1 \% \\
\text { from full scale } \\
\end{array}$ \\
\hline & & $(2 \ldots 200) \mathrm{km} / \mathrm{h}$ & $\begin{array}{c}\text { Consolidated error } \\
\pm 0,01 \% \\
\text { from full scale }\end{array}$ \\
\hline \multirow{2}{*}{$\begin{array}{l}\text { Universal constant volume sampling system } \\
\text { for the determination of mass emissions of } \\
\text { pollutants (CVS system model "EMMS-CVS- } \\
\text { 010"), Factory No. 001, Inv. No. } 5345\end{array}$} & \multirow{2}{*}{$\begin{array}{l}\text { Volume flow } \\
\text { measurement }\end{array}$} & $(0,9 \ldots 4,5) \mathrm{m}^{3} / \mathrm{h}$ & $\begin{array}{l} \pm 2 \% \text { from the } \\
\text { measured value }\end{array}$ \\
\hline & & $(120 \ldots 2200) \mathrm{m}^{3} / \mathrm{h}$ & $\begin{array}{l} \pm 2 \% \text { from the } \\
\text { measured value }\end{array}$ \\
\hline \multirow{14}{*}{$\begin{array}{l}\text { Gas analytical system MEXA -7400DEGR, } \\
\text { Fact. No. } 4301482001 \text {, Inv. No. } 4440\end{array}$} & \multirow{2}{*}{$\begin{array}{c}\text { CO content } \\
\text { in gas sample }\end{array}$} & $(0 \ldots 0,2) \%$ & $\pm 0,01 \%$ (abs.) \\
\hline & & $(0,2 \ldots 0,5) \%$ & $\begin{array}{l} \pm 2 \% \text { (from the } \\
\text { measured value) }\end{array}$ \\
\hline & \multirow[b]{2}{*}{$\begin{array}{l}\text { CO content } \\
\text { in gas sample }\end{array}$} & $(0 \ldots 0,6) \%$ & $\pm 0,03 \%$ (abs.) \\
\hline & & $(0,6 \ldots 12) \%$ & $\begin{array}{l} \pm 2 \% \text { (from the } \\
\text { measured value) }\end{array}$ \\
\hline & \multirow{2}{*}{$\begin{array}{l}\mathrm{CO}_{2} \text { content } \\
\text { in gas sample }\end{array}$} & $(0 \ldots 10) \%$ & $\pm 0,5 \%$ (abs.) \\
\hline & & $(10 \ldots 20) \%$ & $\begin{array}{l} \pm 2 \% \text { (from the } \\
\text { measured value) }\end{array}$ \\
\hline & \multirow{2}{*}{$\begin{array}{l}\mathrm{C}_{\mathrm{m}} \mathrm{H}_{\mathrm{n}} \text { content } \\
\text { in gas sample }\end{array}$} & $(0 \ldots 0,02) \%$ & $\pm 0,001 \%$ (abs.) \\
\hline & & $(0,02 \ldots 5) \%$ & $\begin{array}{l} \pm 2 \% \text { (from the } \\
\text { measured value) }\end{array}$ \\
\hline & \multirow{2}{*}{$\begin{array}{l}\mathrm{CH}_{4} \text { content } \\
\text { in gas sample }\end{array}$} & $(0 \ldots 0,02) \%$ & $\pm 0,001 \%$ (abs.) \\
\hline & & $(0,02 \ldots 0,25) \%$ & $\begin{array}{l} \pm 2 \% \text { (from the } \\
\text { measured value) }\end{array}$ \\
\hline & \multirow{2}{*}{$\begin{array}{l}\text { Total NOx } \\
\text { content in the } \\
\text { gas sample }\end{array}$} & $(0 \ldots 0,04) \%$ & $\pm 0,002 \%$ (abs.) \\
\hline & & $(0,04 \ldots 0,5) \%$ & $\begin{array}{c} \pm 2,2 \% \text { (from the } \\
\text { measured value) }\end{array}$ \\
\hline & \multirow{2}{*}{$\begin{array}{c}\mathrm{O}_{2} \text { content } \\
\text { in gas sample }\end{array}$} & $(0 \ldots 2) \%$ & $\pm 0,1 \%$ (abs.) \\
\hline & & $(2 \ldots 25) \%$ & $\begin{array}{l} \pm 2,3 \% \text { (from the } \\
\text { measured value) }\end{array}$ \\
\hline \multirow[b]{2}{*}{$\begin{array}{l}\text { Mass fuel flow meter of Coriolis type } \\
\text { FlexCOR CMF-BEQ0B1AWCJ2100A, Fact. } \\
\text { No. 237510, Inv. No. } 4167\end{array}$} & \multirow{2}{*}{$\begin{array}{l}\text { Consumption of } \\
\text { substance - liquid } \\
\text { and / or gas } \\
\text { separately or in a } \\
\text { mixture (liquid } \\
\text { and / or gaseous } \\
\text { fuel) }\end{array}$} & $(0,3 \ldots 12) \mathrm{kg} / \mathrm{h}$ & $\begin{array}{l} \pm 1 \% \text { (from the } \\
\text { measured value) }\end{array}$ \\
\hline & & $(12 \ldots 250) \mathrm{kg} / \mathrm{h}$ & $\begin{array}{l} \pm 0,5 \% \text { (from the } \\
\text { measured value) }\end{array}$ \\
\hline
\end{tabular}




\begin{tabular}{|c|c|c|c|}
\hline $\begin{array}{c}\text { Name of measuring equipment, type, } \\
\text { brand, serial number }\end{array}$ & $\begin{array}{l}\text { The indicator is } \\
\text { set or determined }\end{array}$ & $\begin{array}{l}\text { Range or technical } \\
\text { characteristics }\end{array}$ & $\begin{array}{l}\text { Border acceptable } \\
\text { basic errors }\end{array}$ \\
\hline $\begin{array}{l}\text { Gravimetric fuel flow meter AVL mod. } \\
\text { 733S.18, Fact. No. } 0587 \text {, Inv. No. } 3386\end{array}$ & $\begin{array}{c}\text { Fluid consumption } \\
\text { (liquid fuel, etc.) }\end{array}$ & $(0 \ldots 150) \mathrm{kg} / \mathrm{h}$ & $\begin{array}{l} \pm 0,4 \% \text { (from the } \\
\text { measured value of } \\
\text { the fuel mass in the } \\
\text { range } 50 \ldots 1800 \mathrm{~g} \text { ) }\end{array}$ \\
\hline \multirow{2}{*}{$\begin{array}{l}\text { Mass air flow meter } \\
\text { GF-90-A1A00ADAA00060DA5A4, } \\
\text { Fact. No. 237506, Inv. No. 4153 }\end{array}$} & \multirow{2}{*}{$\begin{array}{c}\text { Gas } \\
\text { consumption }\end{array}$} & $(8 \ldots 64) \mathrm{m}^{3} / \mathrm{h}$ & $\begin{array}{c} \pm 1,5 \% \text { (from the } \\
\text { measured value) }\end{array}$ \\
\hline & & $(64 \ldots 1200) \mathrm{m}^{3} / \mathrm{h}$ & $\begin{array}{l} \pm 1,0 \% \text { (from the } \\
\text { measured value) }\end{array}$ \\
\hline $\begin{array}{l}\text { Aneroid barometer BAMM-1, } \\
\text { Fact. No. } 8380, \text { Inv. No. } 1330\end{array}$ & $\begin{array}{c}\text { Atmospheric } \\
\text { pressure }\end{array}$ & $(81 \ldots 106) \mathrm{kPa}$ & $\begin{array}{l} \pm 0,17 \mathrm{kPa} \\
( \pm 0,16 \%)\end{array}$ \\
\hline \multirow{2}{*}{$\begin{array}{l}\text { The psychrometric hygrometer VIT-2, } \\
\text { Fact. No. D212, Inv. No. } 5507\end{array}$} & Relative humidity & $(20 \ldots 90) \%$ & $\pm 5 \ldots 7 \%$ \\
\hline & Air temperature & $(15 \ldots 40){ }^{\circ} \mathrm{C}$ & $\pm 0,2{ }^{\circ} \mathrm{C}$ \\
\hline \multirow{3}{*}{$\begin{array}{c}\text { Climate control device, electronic } \\
\text { TESTO } 608 \text { - H2, Fact. No. } 3003502 \text {, } \\
\text { Inv. No. } 5083\end{array}$} & Relative humidity & $(2 \ldots 98) \%$ & $\begin{array}{c} \pm 2 \% \text { relative } \\
\text { humidity } \\
\left(\text { at }+25^{\circ} \mathrm{C}\right)\end{array}$ \\
\hline & Air temperature & $(-10 \ldots+70)^{\circ} \mathrm{C}$ & $\pm 0,5^{\circ} \mathrm{C}$ \\
\hline & Dewpoint & $(-40 \ldots+70)^{\circ} \mathrm{C}$ & - \\
\hline $\begin{array}{c}\text { Multimeter MY64, } \\
\text { Fact. No. 20000425293, Inv. No. } 1769\end{array}$ & Temperature & $(-40 \ldots 1100)^{\circ} \mathrm{C}$ & $\pm 20^{\circ} \mathrm{C}$ \\
\hline \multirow{2}{*}{$\begin{array}{l}\text { Thermoelectric converters TP-0198/1 XA } \\
\text { (4 pcs.), Fact. No. 484, 486, 489, 490, Inv. - }\end{array}$} & \multirow{2}{*}{ Temperature } & $(-40 \ldots 333){ }^{\circ} \mathrm{C}$ & $2,5^{\circ} \mathrm{C}$ \\
\hline & & $(333 \ldots 1100){ }^{\circ} \mathrm{C}$ & $\pm 0,0075 \mathrm{t}^{\circ} \mathrm{C}$ \\
\hline \multirow{3}{*}{$\begin{array}{l}\text { Diagnostic complex BOSCH. } \\
\quad \text { Motor tester FSA 560, } \\
\text { Fact. No. 65064222, Inv. No. } 3701\end{array}$} & $\begin{array}{c}\text { The temperature } \\
\text { of the oil }\end{array}$ & $(-20 \ldots 150){ }^{\circ} \mathrm{C}$ & $\begin{array}{r} \pm\left(0,01\left(\mathrm{~N}^{1)}\right.\right. \\
-25)+1){ }^{\circ} \mathrm{C} \\
\end{array}$ \\
\hline & \multirow{2}{*}{$\begin{array}{l}\text { Speed of rotation } \\
\text { of engine } \\
\text { crankshaft }\end{array}$} & $\begin{array}{c}(100 \ldots 12000) \\
\mathrm{rpm}\end{array}$ & $\pm 10 \mathrm{rpm}$ \\
\hline & & $(250 \ldots 7200) \mathrm{rpm}$ & $\pm 10 \mathrm{rpm}$ \\
\hline \multirow{8}{*}{$\begin{array}{l}\text { Gas analytical measuring BOSCH } \\
\text { complex with the system of the analysis } \\
\text { of the fulfilled gases ESA 3. } 250, \\
\text { Fact. No. } 760336499, \text { Inv. No. } 3701\end{array}$} & \multirow{2}{*}{$\begin{array}{l}\text { CO content in } \\
\text { gas sample }\end{array}$} & $(0 \ldots 2,0) \%$ & $\pm 0,06 \%$ (abs.) \\
\hline & & $(2,0 \ldots 10,0) \%$ & $\begin{array}{l} \pm 3 \% \text { (from the } \\
\text { full scale) }\end{array}$ \\
\hline & \multirow{2}{*}{$\begin{array}{l}\text { CH content in } \\
\text { gas sample }\end{array}$} & $(0 \ldots 240) \mathrm{mln}^{-1}$ & $\pm 12 \mathrm{ppm}^{1}$ (abs.) \\
\hline & & $(240 \ldots 9999) \mathrm{mln}^{-1}$ & $\begin{array}{l} \pm 5 \% \text { (from the } \\
\text { full scale) }\end{array}$ \\
\hline & \multirow{2}{*}{$\begin{array}{l}\mathrm{CO}_{2} \text { content in } \\
\text { gas sample }\end{array}$} & $(0 \ldots 10) \%$ & $\pm 0,4 \%$ (abs.) \\
\hline & & $(10 \ldots 18) \%$ & $\begin{array}{l} \pm 4 \% \text { (from the } \\
\text { full scale) }\end{array}$ \\
\hline & \multirow{2}{*}{$\begin{array}{l}\mathrm{O}_{2} \text { content in } \\
\text { gas sample }\end{array}$} & $(0 \ldots 3,33) \%$ & $\pm 0,1 \%$ (abs.) \\
\hline & & $(3,33 \ldots 22) \%$ & $\begin{array}{l} \pm 3 \% \text { (from the } \\
\text { full scale) }\end{array}$ \\
\hline $\begin{array}{l}\text { Stopwatch COCpr-2b-2-010, } \\
\text { Fact. No. 7131, Inv. No. } 11173\end{array}$ & Time & $(0 \ldots 60,0) \mathrm{min}$ & $\begin{array}{c} \pm 0,2 \mathrm{~s} \\
2 \text { class accuracy }\end{array}$ \\
\hline
\end{tabular}

\section{Conclusions}

Experimental bench studies of the Daewoo Lanos car with the A15SMS engine showed that the conversion of the car to LPG has led to improved fuel economy. The reduction in specific fuel consumption on average on the load characteristic is $8.6 \%$. The energy performance of the engine increased slightly, at full load the engine torque during operation on LPG increased by about $3 \%$. The content of carbon monoxide CO and nitrogen oxides NOx in the engine VG when working on LPG is almost the same as on gasoline. Concentrations of CmHn hydrocarbons in the modes of low and medium loads increased, and the content of carbon dioxide $\mathrm{CO}_{2}$ decreased.

Experimental studies of a car in motion on the European urban driving cycle performed on a modeling roller stand showed that the conversion of a car with a gasoline engine to LPG leads to a reduction in fuel consumption, expressed in thermal equivalent, by $10 \%$. The values of mass 
emissions of carbon monoxide per cycle are almost the same for both fuels. Emissions of hydrocarbons from LPG increased from 0.035 to $0.183 \mathrm{~g} / \mathrm{km}$, and of nitrogen oxides from 0.142 to $0.233 \mathrm{~g} / \mathrm{km}$. Mass emissions of carbon dioxide when powering the car LPG decreased from 217.8 to $177.9 \mathrm{~g} / \mathrm{km}$.

Experimental studies of the Euro-2 level car in motion according to the European urban driving cycle have shown that when converting a car with a gasoline engine to the LPG power supply, the Euro-2 norms are met.

In the modes of steady traffic, the consumption of LPG, on average, in the range of speeds from 20 to $60 \mathrm{~km} / \mathrm{h}$ when working with ITV is less than the consumption of gasoline by $18 \%$, and without a variator $-11 \%$. When the car is moving in the speed range from 60 to $100 \mathrm{~km} / \mathrm{h}$, the consumption of LPG when using a variator is $3.6 \%$ higher than the consumption of gasoline, and without a variator $-10 \%$. It should be noted that the traction and speed properties of the car have improved slightly.

\section{References}

[1] Raslavičius L., Keršys A., Mockus S., Keršienė N., Starevičius M. Liquefied petroleum gas (LPG) as a medium-term option in the transition to sustainable fuels and transport. Renewable and Sustainable Energy Reviews, Vol. 32, 2014, p. 513-525.

[2] Chitragar P. R., Shivaprasad K. V., Nayak V., Bedar P., Kumar G. N. An experimental study on combustion and emission analysis of four cylinder 4-stroke gasoline engine using pure hydrogen and LPG at idle condition. Energy Procedia, Vol. 90, 2016, p. 525-534.

[3] Feng J., Zhang Y., Song W., Deng W., Zhu M., Fang Z., Ye Y., Fang H., Wu Z., Lowther S., Jones K. C., Wang X. Emissions of nitrogen oxides and volatile organic compounds from liquefied petroleum gas-fueled taxis under idle and cruising modes. Environmental Pollution, Vol. 267, 2020, p. 115623.

[4] Simsek S., Uslu S. Investigation of the impacts of gasoline, biogas and LPG fuels on engine performance and exhaust emissions in different throttle positions on SI engine. Fuel, Vol. 279, 2020, p. 118528.

[5] Gürbüz H., Şöhret Y., Akçay H. Environmental and enviroeconomic assessment of an LPG fueled SI engine at partial load. Journal of Environmental Management, Vol. 241, 2019, p. 631-636.

[6] Chujko G. V. Handbook of Using of a Car "LANOS". Ukraine, 2007, (in Ukrainian).

[7] Nabiev Z. B. Development of a system of detection of detonation and control of the process of burning in gas engines. Piston and Gas Turbine Engines, Ekspress-Informacija, All Russian Institute of Scientific and Technical Information, Vol. 38, 1993, p. 6-21, (in Russian).

[8] Man'ko I. V. Improving the efficiency of liquefied petroleum gas on a wheeled vehicle. Zbirnyk Naukovyh Prac' DonIZT, Vol. 34, 2013, p. 91-94, (in Ukrainian).

[9] Bolbas M. Engine of a gas balloon car: operatability and economy. Avtomobil'nyj Transport, Vol. 3, 1990, p. 28-30, (in Russian).

[10] Kucenko A. C. Mathematical Modeling and Identification of Working Processes of Internal Combustion Engines on Alternative Fuels. Institute of Problems of Machine Building, Moscow, 1995, (in Russian).

[11] Ignatovich I. About the Toxicity of Gas Balloon Cars. Car Transport. Transport, Moscow, 1991, (in Russian).

[12] Nabiev Z. B. Development of an engine operating on compressed natural gas. Piston and Gas Turbine Engines, Ekspress-Informacija, All Russian Institute of Scientific and Technical Information, Vol. 37, 1993, p. 2-13, (in Russian).

[13] Arshavskij E. Ja. Investigation of Possibilities of Recirculation of Used Gases as Method of Lowering Toxicity of Car Engines with Spark Ignition. Moscow Car and Road Institute, Moscow, 1979, (in Russian).

[14] Tarasov A. Pedestrians are to be loved. Avtomobil'nyj Transport, Vol. 3, 1996, p. 42-43, (in Russian).

[15] Bankovskij A. Ju. Review of gas fuel systems of the fourth generation of gas balloon equipment of cars. Transport na Al'ternativnom Toplive, Vol. 5, 2008, p. 24-28, (in Russian).

[16] ISO 14224:2016. Petroleum, Petrochemical and Natural Gas Industries - Collection and Exchange of Reliability and Maintenance Data for Equipment, 2016. 
[17] ISO 3929:2003. Road Vehicles - Measurement Methods for Exhaust Gas Emissions during Inspection or Maintenance, 2003.

[18] ISO 10239:2014. Small Craft - Liquefied Petroleum Gas (LPG) Systems, 2014.
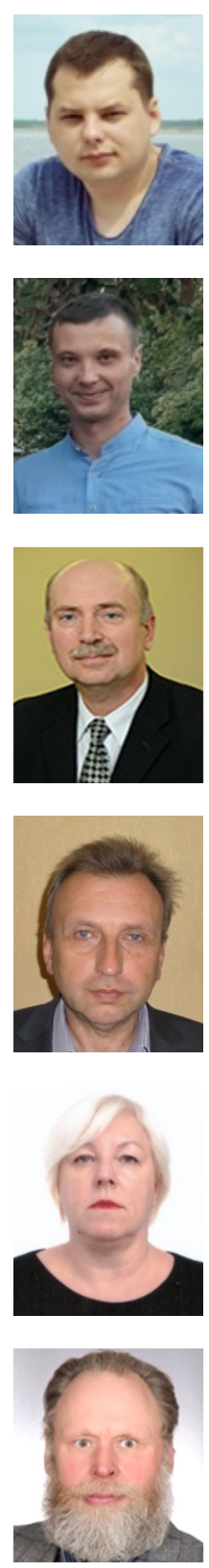

Jurate Ragulskiene has a Ph.D. degree in mechanical engineering from Vytautas Magnus University Agriculture Academy. She is Associate Professor at the Department of Mathematical Modelling of Kaunas University of Technology. Her research interests are mathematical modelling and numerical simulations. J. Ragulskiene was responsible for validation, investigation.

Serhiy Gutarevyc has a Ph.D. degree in mechanical engineering from National Transport University. He is Associate Professor at the Department of Motor Vehicle Maintenance and Service of the Faculty of Automotive and Mechanical Engineering of the National Transport University. His research interests are mobile machines and transport machinery. S. Gutarevyc was responsible for methodology, investigation.

Anatolii Korpach has a Ph.D. degree in mechanical engineering from National Transport University. He is Professor at the Department of Engines and Thermal Engineering of the Faculty of Automotive and Mechanical Engineering of the National Transport University. His research interests are automobile engines and alternative fuels. A. Korpach was responsible for data curation, investigation.

Arvydas Pauliukas has a Ph.D. degree in mechanical engineering from Kaunas University of Technology. He is a Lecturer of the Institute of Power and Transport Machinery Engineering of the Faculty of Agricultural Engineering of Vytautas Magnus University. His research interests are vibrations in mobile machines and transport machinery. A. Pauliukas was responsible for visualization, writing - review and editing. 